\title{
French move past Généthon to gene-therapy research
}

Paris. The French muscular dystrophy association (AFM) and the Centre d'Etude du Polymorphisme Humain (CEPH), which together created the Généthon laboratory in 1990, will soon part company. Généthon will stop its mapping programme this summer after a run of scientific successes, including a 'second-generation' genetic map of the human genome and the physical map of chromosome 21 (see Nature 359, 380 \& 794; 1992), and AFM's substantial resources will subsequently go towards eliminating bottlenecks in gene-therapy research. Daniel Cohen will return to his roots at $\mathrm{CEPH}$, where he will build the sequel to Généthon, an industrial-scale gene discovery centre (see Nature 359, 526; 1992).

Cohen says that Généthon will have finished crude maps of the genome by June and that the work will be continued by genome centres worldwide, including two in the United States that he helped to create. "We have accomplished what we set out to do, this is the end of the game", he says.

But Piotr Slonimski, head of the new French genome agency, is reluctant to abandon an area in which France has excelled and he says that much remains to be done. He wants to maintain the mapping centre, but says that the agency has no plans as yet to pay for the cost of operating Généthon. Another possibility is that research groups elsewhere might pay for use of the centre.

In shifting its support to gene therapy, AFM has no illusions of repeating its spectacular foray into genome research. It recognizes that it cannot support the enormous cost of research, even for a single disease, and that success is elusive. Instead, AFM will combine its $\$ 16.9$ million annual contribution to Généthon with money from other charities to help researchers address the major structural drawbacks to gene therapy research in France.

"What we need most are more sorts of vectors and the large amounts required for tests in animals and humans", says Axel Kahn, director of the INSERM Laboratory of Research on Genetics and Molecular Pathology at the Cochin Institute of Molecular Genetics in Paris.

AFM's solution is to create a host of biotechnology companies at the Généthon site in Ivry outside Paris and to guarantee their profitability by generous subsidies. Kahn says such companies would relieve researchers of much of the laborious work in producing new constructs; he believes that US scientists have made so much progress because of the existence of such companies as Somatic Therapy, Genetic Therapy and Viagene. There are no such companies in Europe, let alone in France. AFM will also create a new laboratory at the Ivry site dedicated to testing the effect of adding unknown genes to mice and to creating animal models for particular diseases.

Cohen agrees that it is more appropriate for medical charities to ease scientific bottlenecks than to fund long-term research programmes, which he sees as the government's responsibility. He says he has always encouraged AFM to "strengthen the scientific community and promote the scaling-up of biology research". But although he approves of the new direction, he says that "it's not for me" because it would not suit his preference for industrial-scale research.

Instead, Cohen will return to CEPH in central Paris, which he created in 1982 with Jean Dausset, a Nobel prizewinner in medicine. Cohen intends to expand CEPH and to double its budget of FF40 million (US\$8 million) by the end of the year through the recently created Jean Dausset Foundation, which has given him FF100 million to develop a 3,000-square-metre laboratory at $\mathrm{CEPH}$.

Cohen says he will build an industrialscale centre, bigger than Généthon and using prototype technology, to discover genes involved in multigenic diseases such as cancer and cardiovascular disorders. He also hopes to attract other companies to the site.

The move towards gene-therapy research in France coincides with the expected first approval within the next few weeks of a gene-therapy trial involving patients with adenosine deaminase (ADA) deficiency. This will be carried out by Alain Fischer, who

\section{IMAGE UNAVAILABLE FOR COPYRIGHT REASONS}

\section{Daniel Cohen outside Généthon}

heads France's largest gene therapy group at the Hôpital Necker in Paris, in collaboration with Dinko Valerio in the Netherlands (see Nature 355, 190; 1992).

Although gene-therapy trials were approved in 1990 when the national bioethics advisory committee declared that somatic gene therapy posed no special problems, Fischer found the approval procedure more difficult than he anticipated. The trial was approved as safe by the state genetic engineering commission but had to go before an additional internal INSERM committee to meet a requirement that groups be insured against any adverse consequences. Moreover, Fischer says that the local ethics committee has dragged its feet because of its reluctance to take risks in the wake of the French blood contamination scandal (see Nature 359, 764; 1992).

Declan Butler

\section{London meetings on British science}

On Friday 19 March, there will be a meeting at the Royal Society, 6 Carlton House Terrace, London SW1, to discuss proposals for the forthcoming White Paper on the organization of British science. The speakers will be Sir Eric Ash (Rector, Imperial College London), Professor Michael Brady (University of Oxford), Dr Dai Rees (Secretary, Medical Research Council) and Sir Mark Richmond (Chairman, Science and Engineering Research Council); the meeting will start at 9.30 a.m. and end at 4.00 p.m.

Admission to the meeting will be by ticket, free of charge, obtainable from Mary Sheehan, Nature, 4 Little Essex Street, London WC2R 3LF. Coffee and tea will be provided.

There will also be a sandwich lunch for those who want it, at a cost of £5: please send a cheque made out to Nature with your ticket application. Tickets for both the meeting and lunch will be sent out during the second week of March.

* On Thursday 18 March, Save British Science is holding a meeting called "Waldegrave meets the scientists" at 12.30 p.m. in the Great Hall, Sherfield Building, Imperial College, London SW 7. The Rt Hon. William Waldegrave, MP, Chancellor of the Duchy of Lancaster and Minister of Public Service and Science, will speak and will answer questions. Entry free. Seats may be reserved by application to Save British Science, PO Box 241, Oxford OX1 3QQ (tel. 0865 273407, fax 511370). 